\title{
Justice Joseph Story on Circuit and a Neglected Phase of American Legal History
}

\author{
R. Kent Newmyer \\ University of Connecticut School of Law
}

Follow this and additional works at: https://opencommons.uconn.edu/law_papers

Part of the Judges Commons, and the Legal History Commons

\section{Recommended Citation}

Newmyer, R. Kent, "Justice Joseph Story on Circuit and a Neglected Phase of American Legal History" (1970). Faculty Articles and Papers. 47.

https://opencommons.uconn.edu/law_papers/47 


\section{HEINONLINE}

Citation: 14 Am. J. Legal Hist. 1121970

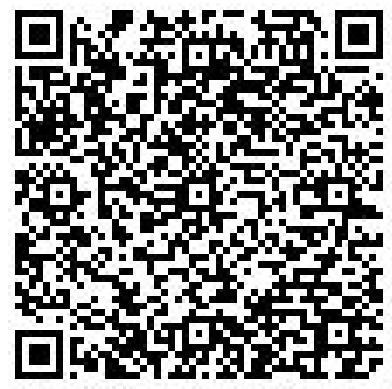

Content downloaded/printed from

HeinOnline (http://heinonline.org)

Mon Aug 15 17:13:21 2016

-- Your use of this HeinOnline PDF indicates your acceptance of HeinOnline's Terms and Conditions of the license agreement available at http://heinonline.org/HOL/License

-- The search text of this PDF is generated from uncorrected OCR text.

-- To obtain permission to use this article beyond the scope of your HeinOnline license, please use:

https://www.copyright.com/ccc/basicSearch.do?

\&operation $=$ go\&search Type $=0$

\&lastSearch $=$ simple\&all $=$ on\&titleOrStd $N o=0002-9319$ 


\section{Justice Joseph Story on Circuit And a Neglected Phase of American Legal History}

by R. KENT NEWMYER*

"Our national history will not have been adequately told [wrote Felix Frankfurter and James Landis] until the history of our judicial system can be adequately told through monographic studies of individual courts." I Probably no more convincing illustration of their observation exists than the old federal circuit courts. From 1789 to 1891 , when they were replaced by the Circuit Courts of Appeals, the circuit courts occupied the broad jurisdictional ground in the federal judiciary between the district courts at the base and the Supreme Court at the apex. Historians have examined the jurisdiction and organization of these courts and have recounted the century-long effort to reform them, ${ }^{2}$ and occasionally a dramatic circuit decision has found its way into a text book on constitutional history. But despite their central position and long history, there has been no comprehensive effort to understand their operation or assess their influence on society and on the development of American law and legal institutions. Without presuming to make up this deficiency, I would, in this exploratory essay, like to show why the circuit courts deserve further study, suggest an approach to that study, and finally, test the approach and spell out its meaning by reference to one circuit (the First) and one circuit judge (Justice Joseph Story, 1779-1845).

* University of Connecticut

1. Felix Frankfurter and James M. Landis, The Business of the Supreme Court: A Study in the Federal Judicial System 52 (1927).

2. Frankfurter and Landis, op. cit. supra. includes the fullest account of the circuit courts. Erwin C. Surrency, "A History of Federal Courts," 28 Mo. L. Rev. 214 (1963) gives an excellent concise discussion of the formal organization and jurisdiction of the circuit courts. Mr. Surrency calls attention to many unanswered problems concerning the circuits and is well aware that answers must come by going beyond the statutes. Ibid., 243. The one general study of the lower federal courts is D. F. Henderson, Courts for the New Nation: A History of the Inferior Federal Courts 1787-1801, Ph.D. Diss., Un. Texas 1966. Mr. Henderson does not carry his study into the period when the circuit courts began to assume their greatest importance, however. 
In terms of jurisdiction alone, the circuit courts clearly played a. central role in the administration of federal law. They possessed original cognizance, concurrent with state courts, of all suits of a civil nature in common law or equity, where the matter in dispute exceeded $\$ 500$ and the United States was a plaintiff, or an alien was a party, or the suit was between citizens of different states. With certain exceptions they also had exclusive cognizance over all serious crimes against the United States. And in addition they had appellate jurisdiction from all final decrees and judgments of the federal district courts where the amount in controversy exceeded $\$ 50$.

Their jurisdiction made the circuit courts the major trial courts in the federal system, but they were much more-legally and historically. To understand their full significance it is necessary to explore the implications of their unique position and function in the federal judicial structure. The Judiciary Act of 1789 , it will be recalled, created three circuits. With the addition of new states the number grew to nine by 1837, where it remained except for a brief period during the Civil War. One Supreme Court justice (two before 1793) was assigned to each circuit and sat, as presiding judge, with the federal district judge in each district of his circuit. The unique, not to say anomalous, feature of this arrangement was that the Supreme Court justice on circuit was still a justice of the Supreme Court. Down to 1869 there were no separate circuit judges, except those created on paper by the short-lived Judiciary Act of 1801, and Supreme Court justices on circuit were therefore, Daniel Webster assures us, considered as "Judges of the Supreme Court . . not Judges of a circuit." 3 Consequently the circuit court became, as James Bayard aptly put it, "an emanation" of the Supreme Court. ${ }^{4}$ And when the justice on circuit spoke he was "considered as bringing the sense of the Supreme Court on the subject" and "seemed to give as satisfactory a conclusion to the business as if the parties had been themselves before the Supreme Court." 5 Armed with this prestige the decisions of the circuit court took on new authority. And while they were subject to review by the Supreme Court, decisions of the circuit court were in most instances final, binding the parties and establishing law for the circuit. ${ }^{6}$

3. Reg. Deb. 19th Cong. 1st Sess. (1826), p. 2515.

4. 11 Annals Cong. 618 (1802).

5. 11 Annals Cong. 103 (1802).

6. There are no statistics available which tell us how many circuit court decisions were carried to the Supreme Court or what the disposition of those decisions was. But available evidence suggests that the 
There was yet another far-reaching ramification of the circuit court's connection with the Supreme Court, one which many contemporaries thought to be its raison d'être. Because the circuit justice was at the same time a Supreme Court justice, he performed a double-edged representative function. First, the justice on circuit was a travelling representative, a living symbol in fact, of national law and authority. Because of his circuit riding, his contact with the people was more direct and regular than that of most elected national officials. In an age when the government in Washington was distant and remote, ${ }^{7}$ the circuit justice could do much to solidify attachment to the nation and its laws.

If the justice represented the Supreme Court to the people, he also represented them to the Supreme Court. It is nearly a forgotten feature of American federalism that the national judicial establishment was structured to accommodate state and sectional interests. Throughout its long history the circuit system was defended because it did just that. ${ }^{8}$ The original three circuits established in 1789 followed sectional lines so far as practicable, and state and sectional self interest played a key role in the creation of new circuits and the rearrangement of old ones. ${ }^{9}$ Circuit justices, more-

great majority of the circuit court decisions stood as law. Justice Story, for example, noted to Justice John McLean, May 25, 1838, that his "spring circuit has been uniformly crowded with business. It has nearly been doubled, \& yet with few or no appeals." McLean Papers, Lib. Cong. Justice Henry Baldwin congratulated District Judge Joseph Hopkinson about their circuit record, too: "We have thus gone through two years without a reversal of any opinion of or Judgt of the Circuit Court on any matter adjudged or delivered by us $\&$ no writ of error or appeal from our Circuit is now depending there." Feb. 20, 1840, Hopkinson Papers, Pa. Hist. Soc.

7. For an interesting discussion of the precarious relation of the people with their national government see: James Sterling Young, The Washington Community 1800-1828 (1966).

8. Defenders of the circuit courts in Congress consistently relied on the courts' representative character. For example see: Senator Jackson of Ga. in 11 Annals of Cong. 50 (1802); Senator Stone of N.C., ibid., 71; Senator Johnson of Ky. in Reg. Deb. 18th Cong. 2d Sess. (1825), pp. 528533; Rep. Polk of Tenn. in Reg. Deb. 21st Cong., 1st Sess., (1830), pp. 549550; Rep. Wickliffe of Ky., ibid., 598-605; Senator Roane of Va. in Cong. Globe 26th Cong., 2d Sess., 213-14 (1841); Senator Weller of Ohio in Cong. Globe, 2d Sess., 296-97 (1855); Senator Cass of Mich., ibid., 298; Senator William Seward of N. Y., ibid., 299; Senator Benton of Mo., Cong. Globe, 40th Cong., 3d Sess. 214 (1869). Congressional opposition to the circuit courts was, as might be expected, based on the fact that they did introduce constituency representation into the federal judiciary.

9. The first circuits were in fact designated by section not number. As established by the Judiciary Act of 1789, the Eastern Circuit consisted of 
over, were appointed in no small part because of their mastery of state and sectional law and generally only after consultation with the dominant judicial and political leaders of the several states involved. Justices were expected "to mingle with those they serve, and learn the manner, habits, and feelings of the people, and acquire to an enlarged extent, the peculiar policy of the several states, their law and local institutions." 10 Knowledge of local law, policy, and institutions was carried to Washington and entered into the deliberations of the Supreme Court; sectional outlook merged with national jurisprudence.

The powers of the circuit court, its structural relation to the Supreme Court, its resulting representative character, then, all point to its potential importance in the federal system of justice and in the life of state and section. To refine and verify this hypothesis it is necessary to study individual circuits, since the nature and lawmaking potential varied considerably from one circuit to the next. Much too depended on the individual circuit justice-whether he perceived the possibilities of his office, whether he was dedicated and talented, and whether his abilities matched the special needs of his circuit. To explain further the nature and importance of the court, then, and to capture something of the behind-the-statutes texture of circuit life, let us examine the First Circuit during the tenure of Justice Joseph Story.

The First Circuit (comprised of Massachusetts, New Hampshire, Rhode Island, and Maine, after 1821) was, thought Chancellor James Kent, "the most pleasant in the U States." 11 It was during Story's tenure also probably the richest in law-making possibilities. Its people were literate, energetic, and enterprising; they were bound together by history and complementary economic interests. Law and legal institutions were mature and highly respected and transcended state boundaries to form a sort of sectional jurisprudence. The bench and bar were among the most learned

N.H., Mass., R.I., Vt., Conn., N.Y.; the Middle of N.J., Del., Md., Va.; and the Southern of N.C., S.C., Ga. The Act of April 29, 1802 (2 Stat. 156) altered the Eastern Circuit by adding the District of Maine and dropping Vt., N.Y., and Conn., which together constituted the Second Circuit. Thereafter the First Circuit remained constant. Curtis P. Nettels, "The Mississippi Valley and the Federal Judiciary, 1807-37" 12 Miss. Valley Hist. Rev. (1925) shows the extent to which sectional self-consciousness influenced views on the expansion and organization of the new judicial circuits which were created down to 1837 .

10. Reg. Deb., 18th Cong., 2d Sess. (1825) p. 529.

11. Kent to Story, August 7,1820 , Joseph Story Papers, Mass. Hist. Soc. 
and spirited in the country. Not least important, established law was being reshaped by the demands of rapid social-economic transformation. The expansion of American shipping that came with the Napoleonic Wars and the rise of manufacturing in the wake of the embargo and the War of 1812 raised a host of new questions in maritime and commercial law. Attacks on American shipping and the American practice of trading with the enemy added further questions of international law, prize, and admiralty. These new questions, many of which confronted the circuit court, required a drastic modification of old legal principles and provided a rich opportunity for creative law-making.

To make use of the potential the circuit justice needed a deep acquaintance with admiralty-maritime and commercial law and an understanding of the operation and changing requirements of the business community. On both counts Story's credentials were impeccable. In talent and temperament he was the essential scholar. His mastery of the authorities, especially in maritime and commercial jurisprudence, gave him a reservoir of legal raw material from which he could fashion law technical and sophisticated enough to meet the demands of the dynamic economy. It is clear, too, that Story was intimately acquainted with the economic structure and the energetic entrepreneurial class that managed it. In family, education, and sentiment he was a New Englander. And what he didn't know intuitively about New England interests he learned during ten years of legal practice in the local and state courts and during his career as Republican politician-in the Massachusetts House of Representatives and as Congressman from Essex South in 1808-1809. His connections with the New England social-economic establishment, once he shrugged off his early radicalism, were impressive. As a member of the Harvard University Board of Overseers (1818) and, after 1829, as Dane Professor at the Law School, he mingled with the luminaries of New England's intellectual universe-Harvard Presidents John Kirkland and Josiah Quincy, Jr., and scholars like George Ticknor, Jared Sparks, John Gorham Palfrey, and Edward Everett. In the overlapping world of business, Story moved with equal facility. George Cabot saw Story's worth as early as 1807 and by 1819 Harrison Gray Otis had come around. He was known and appreciated by the Jacksons and the Lees of Newburyport and Thomas Hansard Perkins, not to mention leading Salem merchants like William Gray, William Orne, and the Crowninshields. He dined with the eminent Israel Thorndike, whose son he taught at the Law School, and with Philip Chadron Brooks, father-in-law of Governor Edward Everett and one of the richest men in New England. Abbot Lawrence, the industrialist and philanthropist, was a close and valued acquaintance. So too were 
many of the politicians of Massachusetts, at least those of Federalist-Whig principles, and especially Daniel Webster. ${ }^{12}$

Story clearly seemed ideally suited and perfectly situated to put the powers of the circuit court to constructive use, but he was not self-sufficient. He relied heavily on the legal profession, both to formulate the law and disseminate its influence throughout the community. Success depended, therefore, on an effective working relationship with the profession. The opportunity was certainly there, for circuit duties made Story a perpetual professional man. There were two terms on the First Circuit, the first running from May 1 through June 27 and the second from October 1 through November 27. And each year Story rode 2000 miles, holding court in Massachusetts at Boston; in Maine, alternately at Portland and Wiscassett; in Rhode Island, alternately at Providence and New Port; and in New Hampshire alternately at Portsmouth and Exeter. Even during vacation he was pressed with circuit business. ${ }^{13}$ Hard work it was but it was also an opportunity, as Webster observed, to inspire "respect and confidence" and produce "a reciprocal communication of information through all branches of the judicial department." 14

Respect and confidence, however, followed ability, and ability had to be demonstrated in the professional confrontation of the courtroom and in the opinions of the judge. The first lawyer the Supreme Court justice on circuit had to impress was his associate on the circuit bench. The exact relationship between the justice and the district judge was nowhere fully specified and accordingly varied all the way from the Third Circuit, where District Judge Hopkinson outshone the mentally unstable Justice Baldwin ${ }^{15}$ to the Fourth, where the district judge, as his partner Justice Duval complained, was so aggressive that he all but stopped the operation of the court. ${ }^{16}$ By virtue of his authority, the Supreme Court justice was expected to lead, but the district judge was no silent partner. Consultation was accepted and agreement necessary as a protection

12. See R. Kent Newmyer, "A Note on the Whig Politics of Justice Joseph Story." 48 Miss. Valley Hist. Rev. (1961).

13. "The business done in the terms does not give an accurate view of the real business of the Court," wrote Story to John Bailey, Dec. 8, 1823. "Almost all of the questions of Law argued in term are taken under advisement \& examined \& decided in Vacation. There are also many important cases, (usually equity causes) which are argued, \& principally in uriting, in vacation, upon which I am obliged to spend a great deal of time in vacation." Story Papers, Mass. Hist. Soc.

14. Reg. Deb., 19th Cong., 1st Sess. (1826), p. 878.

15. Story to Hopkinson, May 9,1833 , Hopkinson Papers, Pa. Hist. Soc.

16. John Catron to John McLean, May 19, 1837, McLean Papers, Lib. Cong. 
against shoddy law and injustice. ${ }^{17}$ District judges often decided cases to relieve an overloaded docket or in the absence of the justice and in many of the remote western circuits did so as a regular thing. ${ }^{18}$ An effective circuit court, then, depended on a harmonious working relationship between the justice and the district judge. The problem facing the circuit justice was the delicate one of leading without dominating.

By his exhaustive learning, infinite tact and patience, and unwearying industry, Story made himself the circuit judge. $\mathrm{He}$ didn't do everything, of course. When the docket was overburdened, which it usually was on the First Circuit, Story shared the load with his partner, sometimes holding court simultaneously in adjoining rooms. In emergencies and occasionally when only routine questions were on the docket, Story gratefully yielded the duties to the district judges. Almost certainly he consulted the special expertise of his fellow judges, as for example he must have done with Judge John Davis of the Massachusetts district, who was one of the ablest admiralty judges in the country. ${ }^{19}$ In his last years on the circuit, he frankly confessed that he meant "to stand upon a fair division of labours with the District Judges." 20

But in fact Judge Story shouldered the lion's share of the circuit burdens and responsibilities for the thirty-three years of his tenure. He handled the infinitude of administrative detail that came in the daily operation of the court-questions from district judges, from officers of the court, from government's attorneys, from parties before the court. ${ }^{21} \mathrm{He}$ was plagued with constant

17. See Ashur Ware to Story, Aug. 8, 1840, Story Papers, Mass. Hist. Soc. for an example of disagreement and consultation.

18. Story to Hopkinson, March 23, 1839, Hopkinson Papers, Pa. Hist. Soc. "I have no doubt that it is entirely competent for either member of the Circuit Court to hold the circuit court in the absence of the other Judge," wrote Story to Hopkinson, "whether such absence be temporary, or permanent in its character, whether it be from causes accidental, or causes permanent in the operation. And such I believe to have been the uniform construction of the Act of 1802 on this subject."

19. See, for example, Story's dedication to Davis in his Commentaries on the Law of Agency (1839).

20. Story to Richard Peters, Sept. 28, 1844, Correspondence of Richard Peters, $\mathrm{Pa}$. Hist. Soc. Story was referring to the late act of Congress which permitted justices of the Supreme Court to omit every other term of the circuit court.

21. For a sample of the questions asked Story see: William Otis to Story, Story Papers, Essex Institute; Charles P. Curtis to Story, May 30, 1820 , ibid.; A. Robbins to N. Searle, Dec. 15, 1817, Story Papers, Lib. Cong.; Story to Hon. Daniel Davis, Sept. 7, 1816, Story Letters, Free Library, Philadelphia, Pa.; William Sullivan to Story, June 27, 1816, Story Papers, Mass. Hist. Soc. 
patronage matters regarding such circuit offices as clerk, marshal, and court reporter. ${ }^{22}$ He kept a close eye on the publication of circuit opinions and assumed a major responsibility for establishing the working rules and prevailing mode of practice in his circuit. Story's main burden, however, was writing opinions. With the ready compliance of the district judges, he handled the important cases that came before the court. ("I had rather take 40 lashes," wrote District Judge Pitman to Story, than try the Warren Case aloneunless Story would send "a note of the points raised in the former trial \& your ruling thereon. . . ."23) It was Story, too, who accepted the progressively burdensome responsibility of clearing the circuit docket each term. ${ }^{24}$ Only one year before his death he complained that the labors of his circuit fell "exclusively" on him. ${ }^{25}$

Story's controlling position on the circuit bench and his influence on the district judges with whom he sat is clear. District Judge John Davis, Story's circuit companion from 1812 to 1841 , pronounced him "everything that could be wished." His "eminent ability and unwearied industry," his "able decisions" and "learned labors," owned Davis, relieved "solicitude" about circuit duties and gave him "salutary aid in various departments of . . . official duty." 26 For district judges of more modest ability, the indebtedness must have been even greater. District Judge Ware of Maine, who sat with Story for twenty years, thought him among the world's greatest jurists and paid eloquent tribute to his services on the circuit bench. ${ }^{27}$ "No person with whom I have associated has exercised so great an influence upon the last half of my life as your lamented husband," confessed Judge John Pitman of the Rhode Island district to Story's widow, "I have lost the stay and staff of my

22. Requests to Story for patronage recommendations involved such offices as Bankruptcy Commissioners; Masters in Chancery; Surveyor and Inspector of the Revenue (for the district); Revenue Collectors; Clerks of the Court; Circuit Court Reporter; District Attorneys; and District Judges. For a sample of requests see: George T. Curtis to Story, Aug. 30, 1841, Story Papers, Mass. Hist. Soc.; John Saunders to Story, Feb. 22, 1841, ibid.; Daniel Webster to Story, May 14, 1818, ibid.; Benjamin Abbot to Story, Sept. 3, 1827, Story Papers, Essex Institute; E. Evans to Story, Feb. 13, 1816, ibid.

23. Pitman to Story, Nov. 22, 1844, Story Papers, Essex Institute.

24. Story to John Bailey, Dec. 8, 1823, Story Papers, Mass. Hist. Soc.

25. Story Papers, op. cit. supra note 24.

26. "Proceedings on the Retirement of Judge John Davis," July 9, 1841 before the Suffolk Bar. 30 Fed. Cases 1304 (reprinted from 1 Story 618).

27. "Proceedings in Maine" at a meeting of the Bar of the Circuit Court, Oct. 1, 1845, in William Story, Life and Letters of Joseph Story (2 vols., 1851), vol. 2, 635-639. 
age and one to whom I always went nor went in vain for advice and sympathy." 28 Story's influence apparently also reached Judges David Howell, Asher Robbins, and Peleg Sprague. ${ }^{29}$

With authority on his own court secure, Story was in a position to influence the legal profession of his circuit, to engender within it that "reciprocal communication" of which Webster spoke. The potential was great but so was the challenge because the circuit judge's talents were there for the profession to see. Judicial weakness might demoralize the whole bar, as Justice McKinley's had on circuit in New Orleans, ${ }^{30}$ or might surrender authority to some dominant lawyer like William Pinkney on the Fourth Circuit, who "like a slave driver" ran roughshod over Justice Duval and Judge Houston. ${ }^{31}$ Judge Story had his work cut out for him in New England. The bar-with the profession of Suffolk and Essex Counties in Massachusetts as the hub-was distinguished and proud. The old elite like Harrison Gray Otis, William Prescott, Nathan Dane, George Blake, Jeremiah Mason, and Samuel Dexter was still around. New arrivals like Daniel Webster and later Charles Sumner, George Hillard, Rufus Choate, Peleg Chandler, and the Curtis brothers, George Ticknor and Benjamin Robbins maintained the tradition. They were equipped and inclined to judge judges with a critical eye.

In establishing his authority with the circuit bar, Judge Story had advantageous connections. He had studied law with two leaders of the Massachusetts profession, Samuel Sewell (later Chief Justice of the Supreme Court of Massachusetts) and Samuel Putnam (who also became a justice on the same court) and won their esteem and lasting affection. During a decade of practice before the courts of Massachusetts (and occasionally New Hampshire) Story had argued against (and with) the leading men of the profession-Prescott, Dexter, Dane, Mason, Putnam, George Blake, and Otis, to mention only some--and convinced them of his ability. His Harvard ties strengthened the professional ones, too, as they did for many lawyers in New England. Of the 294 members of the Suffolk County bar from 1781 to 1840 , for example, no less than 182 were educated at Harvard. The network of associates was intricate:

28. Pitman to Sarah W. Story, Sept. 21, 1845, Letters to Sarah W. Story, Essex Institute.

29. Asher Robbins to Story, Aug. 2, 1826, Story Papers, Mass. Hist. Soc.

30. B. W. Godfrey to Story, April 25, 1841, Story Papers, Essex Institute.

31. John Q. Adams as quoted in Homer Cummings and Carl McFarland, Federal Justice: Chapters in the History of Justice and the Federal Executive 77 (1937). 
Story's colleague on the circuit bench, John Davis, for example, was a classmate of Jeremiah Smith, the great judge of New Hampshire, and of Elijah Paine and Samuel Dexter, leading Massachusetts lawyers. Dexter, in turn, was Story's teacher, a professional colleague of his before 1812, and one of the leaders of the circuit bar. Many of Story's own class of 1798 went into law and some, like Everett Saltonstall, C. P. Sumner, father of Charles and later sheriff of Suffolk County, and Stephen Longfellow, long-time leader of the Portland bar, maintained lifelong professional and personal ties with Story. Even family connections had professional overtones for Story. His father-in-law, William Wetmore, was a distinguished lawyer in Boston and a Judge of the Court of Common Pleas. His brother-in-law and confidant, Samuel Fay, became a probate judge for Middlesex County. His daughter Mary married George Ticknor Curtis, who was an outstanding lawyer and the brother of Benjamin Robbins Curtis, who went on from a distinguished professional career to the Supreme Court of the United States. William Story was, through his father's influence, reporter for the First Circuit from 1839 to 1845.

If many of the lawyers who argued before Justice Story on circuit were former professional colleagues and friends, still more had been his students at Harvard Law School. Story accepted the Dane Professorship there in 1829 and from then until his death in 1845 was the leading teacher and guiding spirit of the school. Attracted by Story's reputation, by the growing library, and by the able supporting labors of Simon Greenleaf, aspiring young lawyers in increasing numbers gave up the precarious apprenticeship system of learning law for the formal discipline of the Law School. Story's influence with the New England profession grew with the school. ${ }^{32}$ In his sixteen years as Dane Professor, Story taught over 800 students. Many of these remained in New England to practice, and the best-like Peleg Chandler, George Hillard, Benjamin Robbins Curtis, George Ticknor Curtis, Rufus Choate, Ebenezer Hoar, Thomas Hopkinson, George Minot, Albert Nelson, Henry Paine, Daniel Richardson, and Charles Sumner-assumed leading roles in the profession. Almost invariably they carried with them a deep admiration and affection for Judge Story. ${ }^{33}$

32. Of the 79 lawyers admitted to the Suffolk Bar from 1829 , when Story assumed duties as Dane Professor, to 1841,24 had studied with him at the Law School. "More than half the younger members [of the Suffolk Bar] had been pupils of the judge," estimated Richard Henry Dana, Jr. in his diary. Quoted in Charles Warren, History of Harvard Law School and of Early Legal Conditions in America (3 vols., 1908), vol. 2, 41 .

33. For an excellent sampling of student reminiscences about the 
What is more important, Judge Story carried from the lecture room at Harvard to the circuit bench the same determination to teach correct law. The profession, it must be said, stood in need of help. The increasing complexity of American society in the early nineteenth century required the lawyer to master a corpus of law rapidly transcending state lines and growing in quantity and sophistication, this without the help of well-established, nationally-oriented law schools and with only primitive aids to legal research. At the same time, the rapid increase in the number of lawyers seriously threatened to undercut professional standards and break down "the sentiment of union and fraternity" of the bench and bar. ${ }^{34}$ The problem was to reinvigorate professional élan and, as Story put it to Kent, "to preserve in the profession a steady spirit of original investigation \& to unite a deep respect for authorities with an habitual inquiry into their consonance with principles." 35

The circuit justice was well situated to teach. His perambulations were a source of communication between the bars of the various districts, and his visits were occasions for social intercourse and professional camaraderie. Most importantly, through his conduct of the court the judge could condition the standards of practice and learning of the bar. Story used the potential to the utmost. Sometimes, as with the practice of equity, the educational chore was very specific. There were no separate courts of equity on the First Circuit, and the legal competence in this crucial area lagged badly. Acutely aware of his responsibility, Story deliberately modeled the practice of equity in his court after that of Chancellor Kent's distinguished chancery practice in New York. In doing so, he hoped not only to "awaken the ardour of the bar" to chancery jurisprudence but to convince the profession to reform that system on the state level. ${ }^{36}$

Specific problems aside, Story conducted his court so as to instill that respect for authorities and that spirit of original inquiry which he thought so vital. The atmosphere of his courtroom was always friendly, urbane, and amicably competitive. ${ }^{37}$ Yet he

greatness and lasting influence of Story as a teacher, see Chapter 26, "Reminiscences of Story," in Warren, op. cit. supra note 32, at pp. 47-69.

34. For a clear statement of this crisis of the profession, see "Notes on the Early Jurisprudence of Maine," 3 Law Reporter 126 (1840).

35. Story to Kent, Aug. 21, 1819, Story Papers, Mass. Hist. Soc. As a young lawyer in Massachusetts, Story had tried to get the state to introduce chancery jurisdiction but was unsuccessful.

36. Story Papers, op. cit. supra note 35.

37. See statement of District Judge Ware in William Story, op. cit. supra note 27 , vol. 2,638 . 
ran a tight ship. He disliked the "exceedingly prolix \& tedious" argumentation before the Supreme Court and kept it at a minimum in his circuit. When a clear understanding of the issues or the law before the court demanded it, or when lawyers drifted away from the point, Story did not hesitate to interrupt (even the great lawyers and personal friends like Samuel Dexter did not escape criticism). ${ }^{38}$ On the other hand, as the circuit reports abundantly testify, he had a keen eye for excellence and generously complimented able arguments at the bar. To the young and inexperienced lawyer, he was especially gentle and encouraging. "He treated us [recalled Richard Dana, Jr.] as though he had our success at Heart. He took care to interweave some compliment, if it was in the least degree deserved, and if our argument was on a false scent, from some ignorance of later decisions, or some error of application, he would bear it patiently, or try to give us the right direction, or the necessary information, in such a way as not only to save our feelings, but to save our credit with our clients and the spectators." 39

Judge Story's efforts to educate the profession were not confined to the circuit courtroom but overflowed into natural channels worn by personal and professional connections. Important leaders of the circuit bar like Charles P. Daveis of Portland and former students at the Law School practicing in New England like Charles Sumner, Peleg W. Chandler, and George Hillard relied on Story for advice and assistance. Government attorneys, marshals, clerks, reporters, district judges, and other legal officers of the circuit called constantly on Story's knowledge. So also did state judicial officers. Prentiss Mellon, Chief Justice of the Supreme Court of Maine, for example, constantly bombarded Story with intricate legal queries. "As you and I are embarked in the common cause of Law," began Story in one of his responses, and in that spirit he answered Mellon in a series of letters which are themselves scholarly essays on knotty problems of the law.40 The constant flow of letters requesting information from lawyers, laymen, friends, and strangers would suggest that Story rarely said no to an honest query on the law. For his personal friends and members of the professional elite, the evidence suggests that Story did much more. In the case of Daniel Webster, for example, Story supplied

38. The anecdote about Story's confrontation with Dexter is told in Simeon E. Baldwin, American Judiciary 363 (1905).

39. Richard H. Dana, Jr. to William Story, May 3, 1851, William Story, op. cit. supra note 27 , vol. 2,318 .

40. See Story to Mellon, Oct. 7, 1824; July 23, 1830; Aug. 28, 1830; Jan. 29, 1831; May 30, 1833; Oct. 9, 1839; March 24, 1840, Story Letters, Yale Un. Libr. 
answers to questions on private and constitutional law, gave him tactical advice on litigation, drafted bills, wrote speeches, gave him political advice, and, in 1834 when conservative going was rough, defended his statesmanship. ${ }^{41}$ Daniel Webster and many other lawyers on the New England circuit knew exactly what William Wirt meant when, with Story in mind, he wished "to Heaven that I had such a Oracle of the law in my neighborhood in the form of a Judge of the Supreme Court." 42

Nor was Story's concern only with the bench and bar of the circuit. The representative theory required that he mingle with the people and "learn their manner, habits and feelings" and that he "bring home the law and justice of his country" to them. ${ }^{43}$ Story's happy relationship with the profession helped him meet this obligation, as did his working alliance with the Establishment. But it was equally important that he knew and was known by the plain people. Here Story was at his best. Friendly, loquacious, and sympathetic, he engaged the common folk whenever he got the chance - which because of his constant circuit riding, was often indeed. Anecdote had it that he came to know more about their business than they did. ${ }^{44}$ They came to know him too and respect him, if only by reputation. (One Sam Whitcomb, Jr. recalled that he had been "taught to respect \& love" Judge Story "from youth" though he had never met him. $)^{45}$ Story aimed to administer not only law to the First Circuit but a legal education as well, and the evidence suggests that when he spoke the people listened.

Story addressed them most directly and didactically in his charges to the grand jury. Grand juries were impanelled in each district of the circuit in order to inquire into and bring presentments in all crimes against the United States. At his discretion the justice could give only a perfunctory statement of the law, leaving the main job of explication to the government's attorney (and this alternative was increasingly common in the 1830's), or he could give a broad, general charge with a close explanation of the law braced by a lecture on sound policy and public morality. The broad charge exactly suited Story's talents for teaching and his bent for didacticism. Meticulously he explained to the jury the nature and meaning of the law it was called to uphold: offenses against the

41. See R. Kent Newmyer, "Daniel Webster as Tocqueville's Lawyer," 11 Am. J. Legal Hist., 127-47 (1967).

42. Wirt to Webster, July 8, 1829, Webster Papers (typed transcript), Lib. Cong.

43. Reg. Deb., 21st Cong., 1st Sess. (1830), 536.

44. Anecdote about Story told by Justice Todd, n.p., n.d., Story Papers, Un. Texas (microfilm).

45. Samuel Whitcomb, Jr., Feb. 13, 1844, McLean Papers, Lib. Cong. 
nation, against public justice and right, against the police and public trade, against persons and property within the jurisdiction of the United States. Emphasis shifted with circumstances. When the passions of war were dangerously strong in 1812 , Story warned against the "persecuting zeal of prerogative and the fury of popular faction" and dwelt heavily on the law of treason, pointing out its limited character. ${ }^{46}$ When Congress made the slave trade piracy in 1819 , Story responded in his charge to the circuit in 1820 with a luminous discourse on the law of piracy and a powerful and passionate condemnation of the nature and evils of the trade. In the same charge, he countered the disuniting spirit generated by the Missouri debates with an encomium on the Constitution, national union, and American patriotism. ${ }^{47}$ Running as themes through all his charges were warnings against the "secret vindictive policies of rulers, 8 the bold, misguided zeal of popular factions" and praise for an "enlightened and virtuous" citizenry. ${ }^{48}$ These charges were frequently printed in newspapers and sometimes circulated in pamphlet form. Backed by Story's reputatjon, they helped make, it is safe to estimate, those "enlightened and virtuous" citizens which he felt were necessary for the preservation of the Republic.

The true measure of Story's impact-and of the circuit court's importance-was not his professional ties or his rapport with the people but his circuit opinions. Here again his efforts were by design broadly educative. From the nature of things circuit opinions called forth the best in the judges-instilled in them, as one congressman put it, "a pride of opinion as well as an ambition to be right." The circuit justice's decision was law for the people of his jurisdiction (unless and until reversed by the Supreme Court), and their life and property were directly and obviously in his hands. So to a large extent were business operations, for the circuit decisions were the framework for the regular and orderly conduct of economic affairs. If he needed more enticement to excellence, the circuit justice had only to recall that he was a member of the community he served and a direct witness to the success or failure of his efforts. He followed his own light, then, and stood or fell on his own merits.

Exactly because of this responsibility-and the power that went with it-Story relished the chore of writing circuit opinions. "I have sometimes said, to particular friends," he wrote to Joseph Hop-

46. Charge to the Grand Jury, 1812 (Ms), Story Papers, Un. Texas (rnicrofilm).

47. Charge to the Grand Jury delivered at Portland, May Term 1820 (Ms), op. cit. supra note 46.

48. Charge to the Grand Jury, 1818 (Ms), op. cit. supra note 46. 
kinson, "if my name shall happen to go down to posterity, my character as a Judge will be more fully $\&$ accurately seen in the opinions of the Circuit Court than in the Supreme Court. In the former I speak for myself after full research \& elaborate consideration $\&$ in the exercise of my own free judgment. In the latter I speak for the Court, \& my free Judgments are modified, controlled \& sometimes fettered by the necessary obedience to the opinions of my Brethren." ${ }^{49}$ So important did Story consider his circuit opinions to be that when, in 1825, his manuscript opinions for three years were destroyed by fire before they could be published, he undertook the laborious task of rewriting them all. ${ }^{50}$

Free to develop his own style of opinion, Story mixed his exhaustive learning with a deep practical knowledge of the "real world" of New England, as he liked to call it. Learned his opinions certainly were. No man in America save possibly Chancellor Kent had such a command of black letter. And despite a constantly overloaded docket, Story never ventured to write a circuit opinion, he boasted to Kent, until he had examined and exhausted "the learning of the Books." 51 In search of usable legal principles, Story went everywhere: to the ancient maritime codes of the Mediterranean states, to Roman law, to continental jurisprudence, to the common law, ancient and modern, and to the state and federal courts of the Union. But his opinions were not essays on abstract legal rules: if he had been inclined to make them such, the duties of the circuit court kept him from it. Whether the subject was banking, agency, corporations, maritime insurance, salvage, bottomry bonds, or the rights of seamen before the mast, Story knew how things worked in practice. His application of authorities was geared closely to the functional needs of the working community, and he drew freely on the practices of the business world in formulating business law. Principle and practice, then, were held in careful balance. And all was clearly organized, lucidly and sometimes elegantly expressed, so that reading Story's circuit opinions, as Kent put it, was like "travelling through the best cultivated Part of England, where Taste \& Judgment \& means render everything beautiful, productive $\&$ perfect." 52

The quantity, quality, and authority of Story's circuit opinions made his court central to the life of New England. In his thirtythree years on the circuit bench, he handed down no less than 734

49. Story to Hopkinson, Febr. 16, 1840, Hopkinson Papers, Pa. Hist. Soc.

50. The volume of reports was in fact published in 1828 . William Story, op. cit. supra note 27, 45-46.

51. Story to Kent, Aug. 31, 1844, Story Papers, Mass. Hist. Soc.

52. Kent to Story, Febr. 8, 1828, op. cit. supra note 51. 
opinions (not counting those delivered but not printed). ${ }^{53}$ Their subject matter followed the contours of sectional life, which is to say, they were predominantly commercial in character-a subject which fitted Story's own talent and preference. Some, like Allen v. McKean,54 De Lovio v. Boit,, 55 and Le Jeune Eugenie, ${ }^{56}$ were treatises on particular aspects of the law but all of them were designed to serve New England's interests. For the lawyer, pressed for sophisticated and up-to-date law but lacking effective digests, reliable treatises, or adequate sources, they were a constant education-especially since Story made it a point to include clear and full references to his sources so that any misapplication of principles might be corrected by others. The business community, too, relied on the decisions of the circuit court, for, as Boston banker Thomas Haven put it, "Lawsuits when decided from fixed principles are useful land marks for the merchant." 57 Story's opinions, of course, were not always accepted without debate, but his leading cpinions in such areas as prize law, 58 maritime law, 59 insurance, ${ }^{60}$ devises, ${ }^{61}$ patents, ${ }^{62}$ and equity ${ }^{63}$ provided businessmen

53. The count of 734 is taken from Federal Cases which includes some cases not included in the regular circuit reports. Evidence is that there were opinions, some of which were referred to in contemporary law journals, which were delivered but which are not to be found in either Federal Cases or the circuit reports.

54. 1 Sumner 276 CCD Maine, 1833.

55. 2 Gall. 398 CCD Mass. 1815.

56. Nowhere reported.

57. Haven to Francis Hopkinson, March 9, 1836, Hopkinson Papers, Pa. Hist. Soc.

58. William Story (op. cit. supra note 27 , vol. 2,575 ) singles out as his most important judgments: The Julia (1 Gall. 594); Schooner Rapid (1 Gall. 295); Brig Joseph (1 Gall. 545); Marianna Flora (3 Mason 116); Ship Ann Green (1 Gall. 274).

59. Among those singled out by William Story (op. cit. supra note 27, vol. 2, 576), are: Schooner Tillon (5 Mason 465); Schooner Volunteer (1 Sumner 571); Harden v. Gordon (2 Mason 319); Ship Mentor (4 Mason 84).

60. Peale v. The Merchant's Insurance Co. (3 Mason 27); W. Story, op. cit. supra note 27 , at p. 576.

61. Parkman v. Bowdoin (1 Sumner 359); Sisson v. Seabury (1 Sumner 235); Durant v. Ritchie (4 Mason 45); Gardner v. Gardner (3 Mason 178). William Story, op. cit. supra note 27, vol. 2, 581.

62. Wyeth v. Stone (1 Story 273); Brooks v. Byam (2 Story 525, 553); Washburn v. Gould (3 Story 122); Barrett v. Hall (1 Mason 448). W. Story, op. cit. supra note 27, vol. 2, 584.

63. Harvey $v$. Richards (1 Mason 381); Hough v. Richardson (3 Story 660); Flagg v. Mann (2 Sumner 487); Doggett v. Emerson (3 Story 700); Jenkins v. Eldredge (3 Story 183, 300, 325); Veazie v. Williams (3 Story 54, 
with a clear, rational, dependable basis for their entrepreneurial decisions.

The dissemination of these opinions throughout the community was facilitated by the two leading legal periodicals of New England-The American Jurist and Law Magazine and The Law Reporter. Both were aimed at the working lawyer as well as the mercantile community (though the former was more theoretical and broad-based). Both were edited by Story's former students (the Reporter by Peleg Chandler and the Jurist from 1836-1843 by Charles Sumner, Luther Cushing, and George Hillard). And both gave quick and extensive coverage and analysis of Story's circuit opinions. Story sensed their important contribution to the circulation of his rulings and cooperated with their editors by forwarding manuscript opinions and in general supporting and encouraging them. ${ }^{64}$

George T. Curtis and Taney's biographer Samuel Tyler concluded independently that the full measure of a circuit justice could not be taken from his opinions alone. ${ }^{65}$ They might have added that the full meaning of the circuit court itself was not apparent from its printed reports. Certainly the key to Circuit Judge Story and his court lay in the mutual complementarity of his various functions, judicial and non-judicial. Because he knew the people and their interests, his opinions were relevant to their needs. Because his law was relevant and because his ability and integrity were known, the people had confidence in his pronouncements. The network of relationships built from friendship, professional contact, and the performance of his official duties, in turn, became means for the explication and dissemination of his legal rulings.

The First Circuit Court under Story, in short, became a vital institution in the life of New England. His efforts, of course, were not universally applauded. During the War of 1812 and immediate-

612); Wood v. Dummer (3 Mason 309). W. Story, op. cit. supra note 27, vol. 2, 586-587.

64. "Can you oblige me so much as to allow me to print some of your recent opinions in the next number of the Law Reporter?" wrote Chandler to Story. "If you should deem it more proper, I will make an abstract of one 8 print that only, although I should be extremely happy, while I am so near the beginning of a volume to print one of your opinions in extenso." May 11, 1844, Story Papers, Essex Institute. Story was in the habit of loaning out his circuit opinions, it would appear. "You are very welcome to use the case of the Henry Eubank to publish in the Jurist . . . ," wrote Story to Willard Phillips (the editor of the Jurist in 1834). Story also agreed to correct the proofs for him. Story to Phillips, Febr. 6, 1834, Story Papers, Mass. Hist. Soc.

65. B. R. Curtis to Webster, Nov. 16, 1851, Webster Papers, Lib. Cong. Samuel Tyler, Memoir of Roger Brooke Taney, LL.D. 308 (1872). 
ly after, for example, his aggressive nationalism and unyielding enforcement of the laws against trading with the enemy offended members of the Federalist elite. ${ }^{66}$ As might be expected, there was periodic opposition to certain of Story's opinions, as for example the important bankruptcy decision in Ex Parte Foster ${ }^{67}$ Possibly too, the Judge's popularity was not entirely uniform throughout the circuit; at least Richard H. Dana, Sr. discovered that he "is not liked much" in Providence. ${ }^{68}$ But all factors considered, there is every reason to accept George T. Curtis's evaluation: "It must be long before that public confidence follows the Court again, which now rests upon all its doings, if you retire from the Bench," he wrote to Story in 1844 in reference to Story's rumored resignation from the Supreme Court. "The public have been so long accustomed to know that a decision of your's is the Law, drawn from all its sources and resting on its broad foundations, so many of the commercial and professional classes have grown up under your administration, that whenever you retire, it will be seriously felt." 69

\section{III}

If the circuit court was, as Curtis's assessment of Story's court suggests, a basic institution in the life of state and section, it was also a working part of the federal judicial system. It is not surprising, therefore (though historians have hardly noticed the point), to find that in several ways, the circuit system left a distinctive mark on national law and legal institutions. The First Circuit under Story might again serve as a point of illustrative departure.

In a strict legal sense, the impact of the circuit court was confined to its own jurisdiction, since circuit decisions were law only for the circuit. Circuit decisions could get a national hearing, however, providing the case was of general interest and the opinion sufficiently authoritative to command professional attention. Such was the case on the First Circuit. The commercial character of its litigation raised exactly those legal questions which interested a nation in the midst of economic expansion. And Story's authoritative rendering of those questions quickly won him a national audience. The same legal journals that circulated Story's opinions through the

66. See for example Otis' bitter attack on Story and his opinion in The Bothnea. The Janstoff, 3 Fed. Cas. 962, no. 1686 (CCD Mass. 1814). See my article, "Joseph Story and the War of 1812: A Judicial Nationalist," 26 The Historian 486-501 (1964).

67. 9 Fed. Cas. 508 , No. 4, 960 (CCD Mass. 1842).

68. Richard H. Dana to Richard H. Dana, Jr., Nov. 28, 1838, Dana Papers, Mass. Hist. Soc.

69. Curtis to Story, Dec. 13, 1844, Story Papers, Essex Institute. 
New England Circuit also carried them beyond. The American Jurist and Law Magazine was one of the outstanding legal periodicals of the age and had a national circulation. Chandler's Law Reporter was also read widely outside New England. (In 1844, for example, Chandler boasted of 100 subscribers in Ohio and 50 in Louisiana alone and estimated that the Reporter had a larger subscription than Peters' Supreme Court reports.) ${ }^{70}$ Professional journals in other states-like The Western Law Quarterly (Ohio), the Pennsylvania Law Journal, and The New York Legal Observer ${ }^{71}$-also gave notice to important decisions from the First Circuit. Even non-legal journals and newspapers like the North American Review, the National Advocate, Niles' Weekly Register, and the National Intelligencer had occasion to praise Story's circuit labors. ${ }^{72}$ Specialized legal treatises, a genre just coming into its own during this period, also found much instruction in Story's circuit opinions and advertised the First Circuit among the profession.

With billing like this, and with Story's reputation on the Supreme Court and at the Law School in addition, it can hardly be doubted that the circuit reports from the New England Circuit commanded the attention of practising lawyers and legal scholars throughout the country. Many able lawyers recognized the advantage of keeping current with the decisions of the various circuit courts and Story's circuit attracted special attention. J. J. Gilchrist, for example, thought a digest of all circuit court reports would "command an extensive sale" and mentioned Story's opinions as "preeminently valuable." ${ }^{73}$ Lacking such a digest, lawyers did their homework by correspondence. One lawyer, practising in the federal courts of the Second Circuit, noticed mention of a prize decision made by Story on the Rhode Island Circuit and wrote to Henry Wheaton for the principal points covered. ${ }^{74}$ Another from Georgia wrote directly to Story for a clarification on an opinion in 4 Mason which he had read "with great pleasure" and thought applicable to his own practice. ${ }^{75}$ Judge Van Ness of the Federal 69.

70. Chandler to Story, May 11, 1844, Story Papers, op. cit. supra note

71. See: 1 Western Law Journal 42-44, 84-86, 201 ff (1844); ibid., 46575; 2 Western Law Journal 39ff (1845); 1 New York Legal Observer 212213, 232-233, 324; ibid., vol. 2, 97-99.

72. 8 North Am. Rev. 253-276 (1819). 4 Niles' Weekly Register 393-397 (Aug. 21, 1813); ibid., vol. 9, 187-88 (May 18, 1816).

73. Gilchrist to Sumner, Aug. 25, 1846, Sumner Papers, Houghton Lib., Harvard.

74. William Van Ness to Wheaton, July 1, 1813, Wheaton Collection, Pierpont Morgan Lib.

75. T. F. Foster to Story, Dec. 7, 1836, Story Papers, Mass. Hist. Soc. 
District Court of New York also followed Story's circuit opinions closely. "It is not a decision of the Supreme Court," wrote Van Ness in citing one of Story's circuit opinions, "but of a very enlightened judge, who elucidates every subject he examines with great ability and research, and whose judgments are entitled to the confidence and respect of every tribunal acting under the laws of the United States." 76 Chancellor Kent, who read Story's circuit opinions with the avidity of a "young Romancer" reading Sir Walter Scott, agreed entirely with Judge Van Ness. On the First Circuit, he declared, "I am sure to find the law of the land expounded \& enforced with the most extensive learning, the best Taste, the loftiest Morals, the most unshaken Independence \& freedom \& the most attractive Graces of Style \& Eloquence." 77 Not surprisingly, Story's circuit opinions found a conspicuous place in Kent's impressive and widely-read Commentaries on American Law. ${ }^{78}$

Circularization and discussion of circuit law also took place among the justices of the Supreme Court thanks to an anomaly in the structure of the circuit court system. The anomaly was that identical cases in different circuits could be decided differently; and unless one of the decisions were reviewed by the Supreme Court, both conflicting decisions would remain law within their respective jurisdictions. To avoid such conflict when possible and to inject a compensating measure of uniform interpretation into circuit law, several Supreme Court justices, along with some district judges corresponded regularly about circuit decisions. After completing their circuits, for example, Justices Story and Bushrod Washington regularly exchanged long letters summarizing key decisions and calling attention to important rules of law established. ${ }^{79}$ Story also corresponded about circuit matters with Justices Henry Brockholst Livingston, Smith Thompson, and Chief Justice Marshall and with Federal District Judge Joseph Hopkinson as well. Makeshift though it was, this informal clearing house gave a national dimension to circuit law and, for Story, since the balance

76. Juando v. Taylor, 2 Paine 652,13 Fed. Cas. No. 7,558 at 1188 (CCD New York, Aug., 1818).

77. Kent to Story, June 23, 1837, Story Papers, Mass. Hist. Soc. Kent, it might be added, liked the court opinions even more after the Jacksonians captured the Supreme Court.

78. Commentaries on American Law (4 vols., 1826-1830). The work went through three editions in Kent's lifetime, the last being in 1846.

79. For example, see the following Story-Washington letters in the Story Papers at the Mass. Hist. Soc.: June 19, 1821; Aug. 9, 1821; Dec. 4, 1821; Nov. 19, 1822; June 27, 1823; Sept. 11, 1823; July 4, 1827; Aug. 13, 1829. 
of intellectual trade ran in his favor, it was another source of influence. ${ }^{80}$

The circuit court touched national jurisprudence in a more direct and fundamental way through its institutional connection with and influence on the Supreme Court. The justice was expected to bring his special knowledge of law and policy learned on circuit to the full Court in Washington. The evidence, though sketchy, suggests that the circuit judge's expertise carried weight in the Court's deliberations. ${ }^{81}$ Certainly, when a circuit decision came on for review, the justice could be expected to explain the full context of the case at instance level (and the evidence is that he also gave a vigorous defense of his decisions below). ${ }^{82}$

But it was much more than legal expertise and pride of opinion that the justice carried to Washington from his circuit. Constant and direct contact with the community to whom he gave law conditioned his own intellectual world. Not surprisingly, both his social-economic preferences and his legal outlook had a strong correlation to his state and section. Certainly the commercial, conservative nationalism of Story's opinions and treatises followed

80. For a sample of the Marshall-Story correspondence about circuit cases and Marshall's tendency to rely on Story, see the following Marshall letters in the Story Papers, Mass. Hist. Soc.: July 13, 1819; Sept. 18, 1821; July 2, 1823; Nov. 24, 1823; Dec. 9, 1823.

81. Referring to Story's circuit opinion in the important prize case, The Bothnea. The Janstoff, 3 Fed. Cas. 962, no. 1686 (CCD Mass. 1814), which was appealed to the Supreme Court, H. G. Otis deduced "that he will now feel himself pledged to support his opinion, so as to influence his colleagues, some of whom . . . are considered as giving him the pave in all causes of this description." Otis to Robert Goodloe Harper, Dec. 2, 1815, Harper Papers, Lib. Cong. Marshall was, he confessed, "not versed in admiralty proceedings" and deferred to Story in this area. See, for example: Marshall to Story, May 27, 1819; May 23, 1831, Story Papers, Mass. Hist. Soc.

82. As already noted, justices were very sensitive about the Court's reception and treatment of their circuit opinions (note $6 \mathrm{op}$. cit. supra). Baldwin, for example, was upset that a decree from his circuit had been reversed and recalled to Joseph Hopkinson on the circuit bench that "during the time we have sat together there have been only three appeals from our decisions in equity. . . ."Jan. 26, 1835, Hopkinson Papers, Pa. Hist. Soc. When cases did come on for review, judges defended their work below, witness Story's adherence to his circuit position on common law jurisdiction of the federal courts. U. S. v. Hudson and Goodwin, 7 Cranch 32 (1812) and $U . S$. v. Coolidge, 1 Wheat. 415 (1816). He was also pleased that his circuit had few appeals. See Story to McLean, May 25, 1838, McLean Papers, Lib. Cong. Marshall, too, was not inclined to abandon his circuit position lightly. Marshall to Story, June 2, 1823, Story Papers, Mass. Hist. Soc. 
New England priorities. And John R. Schmidhauser's scalogram analysis of Supreme Court opinions from 1837-1860 has shown a correlation between sectional biases and the opinions of other justices. ${ }^{83}$ It was not that the justices weren't nationalists. Probably more consistently than other statesmen of the period, they transcended the idiosyncracies and irrelevancies of state and section, and some, like Wayne or Marshall himself, reacted against the dominant forces of their section. But, like other statesmen of antebellum America, they were tempted to define nationalism in terms of the "good life" of their state or section. The circuit system was not entirely responsible for the sectional values of the justices, but, by institutionalizing sectional contacts, it no doubt introduced an added element of sectional division on the Bench which interrupted the absolute and symmetrical exposition of national jurisprudence. State's rights and sectionalism, however, were facts of American life, in law as well as politics. And anomalous as it might seem, the fact that national law accommodated sectional interests was in no small part responsible for its acceptance by the people. As Congressman John Weller of Ohio said in reference to the "representative system," as he called the circuits: "But for the fact that that court is so organized as to represent the various sections of this Union, that sectional feeling which has now and then broken out in some portions of the confederacy, might ere this, have disturbed the Constitution itself." 84

If the representative function of the circuit system tended to splinter the Court along sectional lines, it united it along pragmatic ones. Work at the trial level taught the justice, as one defender of the circuit system put it, that "technical learning is not all which is necessary." What the justice needed, in addition, was "plain, practical common sense; that knowledge of human nature, of man and things, which is obtained by an intercourse with the world." 85 It is reasonable to connect the general non-doctrinaire quality of Supreme Court law during the formative period, as well as the specific animadversions of Story and Marshall to theory and speculation, to the experience of the justices on circuit.

The circuit court not only influenced the character of the Court's decisions but greatly facilitated their acceptance, and indeed the acceptance of the Court itself, by the people. It is one of the paradoxes of American history that the Supreme Court-with its life tenure, secret deliberations, and mysterious languageshould have endeared itself to the American people at exactly the

83. John R. Schmidhauser, "Judicial Behavior and the Sectional Crisis of 1837-1860," 23 Journal of Politics (1961).

84. Cong. Globe, 33 Cong., 2 d Sess. (1855), 296-97.

85. Reg. Deb., 21st Cong., 1st Sess. (1830), 567. 
time that they were moving toward representative democracy. There are several reasons, of course, for this phenomenon, but the fact that the circuit courts injected the "representative principle" into the federal judiciary is of no small significance. To be sure, the Court still possessed large powers beyond the direct control of the people. But knowing the men who exercised those powers, seeing them regularly on circuit, knowing that they knew the needs of state and section and that those needs would get a hearing in Washington eased democratic misgivings and deflated abstract arguments against a national judicial aristocracy. Senator William Seward grasped the whole issue. "Of all the departments of Government," he observed during debate over the circuit courts, "the judiciary is the only one which approaches this absolute in its form. It is protected and secured against responsibility to the people on all sides. That I believe to be necessary, and, therefore, I have always acquiesced in it; but I think it was brought within the general principles of our republican system of Government, by the provision which requires the Judges of the Supreme Court to attend to the transaction of business at nisi prius; and that is the last feature in the judicial system which I shall be willing to give up. ${ }^{86}$ The circuits were, in fact, not given up until the Supreme Court had established its institutional character and won its democratic credentials by service to the needs of the majority of the American people.

The circuit courts, it would seem clear, constituted a significant chapter in American legal history, one which-to return to the admonition of Frankfurter and Landis-deserves scholarly attention. The formative role which these courts played in the life of the people of the circuits, if one were to judge from the First Circuit during Story's tenure, would be reason alone to study them. Nor does it matter that not every circuit had the potential of the First or every judge the unusual ability of a Story. Each circuit had its own possibilities and every judge his own opportunity and should be studied on their own merits. To examine law and legal institutions at this level, where they intersect directly with the interests of society, would provide a healthy corrective to the temptation of legal history to concern itself too much with the great cases at the appellate level. In addition, a study of the circuit system has something to contribute to the understanding of national jurisprudence. The American legal system is a unit, the individual parts of which are vital to the functioning of the whole. If the circuits were, as contemporaries perceived, inseparable from the Supreme Court, it would follow that the Supreme

86. Cong. Globe, 33 Cong., 2d Sess. (1855), 299. 
Court and the law it made will not be fully understood until we know more, individually and collectively, about the circuit courts. Certainly the popular reception of the federal judicial authorityan area about which we know much too little-was significantly influenced by the circuit duties of Supreme Court justices. Finally, though not least of all, study of the circuit courts would, as we have seen in the case of Joseph Story, add a much-needed dimension to judicial biography. Not only did the justices before the 1860's spend a large portion of their time and energy on circuit, but circuit opinions, charges to the jury, and the general conduct of the court put the full range of the justices' abilities to the test, for biographers to see. ${ }^{87}$ Even more important, the circuit experience was calculated to condition the whole social-legal outlook of the justices, giving substance to the experience, "the felt necessities of the time, the prevalent moral and political theories, intuitions of public policy . . . even the prejudices which judges share with their fellow-men" which in addition to logic shaped American law.

87. Story, as we have already seen (supra, p. 17), thought that the circuit would be the most accurate historical measure of his ability as judge. Supreme Court Justice Benjamin Robbins Curtis thought "that every quality $\&$ attainment of which a judge is capable may there (on circuit) find their fullest exercise and their most difficult work." There "in the actual application of the law to the business of men . . . whatever faults, or weaknesses he has, are sensibly felt." B. R. Curtis to Webster, Nov. 16, 1851, Webster Papers, Lib. Cong. 